удк 341.217

DOI https://doi.org/10.32837/apdp.v0i85.1830

О.О. Избаш

\title{
АВТОРСКОЕ ПРАВО И ИНТЕРНЕТ
}

Актуальность. Сегодня в эпоху бурного развития информационных технологий, ускорения процессов информатизации, развития систем массовых коммуникаций, глобализации и интернационализации интернет приобрел функцию мирового информационного ресурса. Стремительное развитие интернета, рост и сложность информационного потока создают условия для актуальности вопроса о защите авторских прав, изменений действующего международного и национального законодательства в отношении ответственности за возникающие нарушения.

Анализ литературы и исследований. На сегодняшний день отмечается повышение внимания проблеме защиты авторских прав в сети Интернет, в литературе, на конференциях, в законодательной сфере и в деятельности отдельных компаний. Однако этот вопрос поднимается все же редко и как правило решения, принятые по нему, все же отстают от реальности. Основные исследования посвящены стандартному способу защиты авторского права, что не всегда может быть применимо к современным технологиям. Авторы редко проявляют креативность в предложенных ими путях решения проблемы, опираясь в своих работах в основном на теоретические познания в юриспруденции и упуская из виду «необычность» интернет-ресурсов. $K$ сожалению, отсутствует сотрудничество между теоретиками и практиками юриспруденции и такими техническими специалистами как программисты в выработке оптимально подходящих способов защиты авторских и смежных с ними прав в интернете.

Цель статьи - проанализировать основные проблемы защиты авторского права в сети Интернет. Исходя из цели исследования, можно сформулировать его основные задачи: характеристика основных вопросов, связанных с нарушениями авторских и смежных прав в интернет-пространстве; охарактеризовать основные проблемы защиты прав правообладателей.

Основной материал статьи. Книги, музыкальные записи, аудиовизуальные произведения перестают продаваться сразу же, как только они становятся общедоступными на пиратских сайтах. Разумеется, правообладатель может обратиться к администрации сайта с требованием об удалении незаконно размещенного контента. Но беда в том, что правообладатель не всегда в состоянии успеть за пиратами. Поэтому гораздо удобнее поручить борьбу с пиратским контентом антиконтрафактному агентству.

Принцип работы антиконтрафактных агентств в сети заключается в рутинном систематическом мониторинге интернет-ресурсов и немедленном реагировании на обнаруженные угрозы. Мониторинг осуществляется оператором агентства как в автоматическом режиме, так и вручную. Систематичность мониторинга определяется спецификой охраняемого объекта. Это может быть как ежемесячный, так 
и ежедневный мониторинг, проводимый как во всей сети Интернет, так и в отдельных ее сегментах. Исходя из такой специфики работы, антиконтрафактные агентства как правило взымают абонентскую плату за услуги по мониторингу интернета.

Охраняемые объекты - это книги, диссертации, любые другие литературные произведения; компьютерные программы; музыкальные и аудиовизуальные произведения; фотографии, изображения, содержащие объекты дизайна, чертежи, проекты; оформление сайтов. Владельцы сайтов, нарушающих авторские права, реагируют на заявленные претензии в соответствии с законом Парето.

Успех антипиратских кампаний в интернете основывается на том, что анонимности в сети не существует, а абсолютное большинство стран связаны международными соглашениями об охране авторских прав. В связи с этим местонахождение владельца сайта и хост-провайдера вполне определимо, а их юрисдикция не имеет существенного значения для успешного проведения юридических процедур. Кроме того, многие поисковые системы, в частности, Google, содействуют правообладателям и удаляют ссылки на пиратский контент из результатов поисковых запросов.

Для организации антипиратских мер в интернете необходимо иметь экземпляр произведения (объекта смежных прав); сведения об авторах и правообладателях (если они не совпадают в одном лице); сведения об условиях распространения произведений; доверенность либо иной документ, подтверждающий полномочия антиконтрафактного агентства. Хотя регистрация объектов авторского права не имеет правового значения для их охраноспособности, наличие такой регистрации значительно упростит переговоры с владельцами сайтов и хост-провайдерами.

26 апреля 2017 года вступил в силу Закон «О государственной поддержке кинематографии в Украине». Этим законом были внесены довольно существенные изменения в закон "Об авторском праве и смежных правах», а также в Уголовный кодекс, Кодекс об административных правонарушениях и ряд других законов. Все эти изменения так или иначе связаны с процедурами защиты авторских прав в интернете.

Сегодня заявитель может обратиться с заявлением о прекращении нарушения исключительно через представительство (при посредничестве) адвоката (ст. 52-1 Закона «Об авторском праве и смежных правах», далее - закона) [1]. Если такое заявление будет неэффективным, то правообладатель имеет право обратиться суд. Изменены нормы об исключительной подсудности споров о защите авторских прав в интернете. Теперь гражданские иски, возникающие по поводу нарушения имущественных прав интеллектуальной собственности с использованием сети Интернет, предъявляются по местонахождению центрального органа исполнительной власти, реализующего государственную политику в сфере интеллектуальной собственности (ст. 114 ГПК) [2].

В связи с ликвидацией Государственной службы интеллектуальной собственности ее полномочия и функции с 18 мая 2017 года переданы Министерству экономического развития и торговли. Соответствующим образом изменились и правила об исключительной подсудности в хозяйственном процессе: дела по спорам о нарушении имущественных прав интеллектуальной собственности рассматриваются хозяйственным судом по месту совершения нарушения. 
Дела по спорам о нарушении имущественных прав интеллектуальной собственности с использованием сети Интернет рассматриваются хозяйственным судом по местонахождению центрального органа исполнительной власти, реализующего государственную политику в сфере интеллектуальной собственности (ст. 16 ХПК).

Институт обеспечения иска в гражданском процессе дополнен нормой о возможности установления обязанности совершить действия по предотвращению доступа пользователей сети Интернет к объектам права интеллектуальной собственности, правомерность использования (размещение) которых в сети Интернет является предметом спора (ст. 152 ГПК).

Объективная сторона преступления, предусмотренного ст. 176 УК (нарушение авторского права и смежных прав), дополнена такими действиями как камкординг и картшейринг. Теперь эти термины определены в самом законе:

- камкординг - видеозапись аудиовизуального произведения во время его публичной демонстрации в кинотеатрах, других кинозрелищных заведениях лицами, находящимися в том же помещении, где происходит такая публичная демонстрация, для любых целей без разрешения субъекта авторского права или смежных прав;

- кардшейринг - обеспечение в любой форме и любым способом доступа к программе (передаче) организации вещания, доступ к которой ограничен субъектом авторского права и (или) смежных прав применением технических средств защиты (абонентская карта, код и так далее), в обход таких технических средств защиты, в результате чего указанная программа (передача) может быть воспринята или иным способом доступна без применения технических средств защиты [3].

Более того, под ст. 176 УК теперь подпадает финансирование всех действий, перечисленных в ч. 1 этой статьи, то есть финансирование любых форм умышленного нарушения авторского права. Заявление о прекращении нарушения авторского права в интернете обязательно должно содержать мотивированное утверждение о наличии у заявителя имущественных прав интеллектуальной собственности на объект авторского права и (или) смежных прав, указанных в заявлении, со ссылкой на основания возникновения таких прав и срок их действия.

Авторские права лучше закреплять документально, чтобы облегчить доказывание в судах факта и даты создания произведения, а также его содержания. Есть два пути такой «регистрации» авторского права: в Министерстве экономического развития и торговли (МЭРТ) и у нотариуса. При отсутствии доказательств автором произведения считается лицо, указанное в качестве автора на оригинале или экземпляре произведения. К сожалению, новые требования закона об обязательной идентификации владельца имущественных прав полностью не учитывают право автора на псевдоним и анонимность.

Ст. 52-1 закона предусматривает, что порядок защиты авторского права и (или) смежных прав, предусмотренный этой статьей, применяется к отношениям, связанным с использованием: аудиовизуальных произведений, музыкальных произведений, компьютерных программ, видеограмм, фонограмм, передач (программ) организаций вещания. Этот список произведений сформулирован как исчерпывающий и объединен понятием «электронная (цифровая) информация». 
Поэтому рассматриваемый здесь порядок не применяется к таким произведениям, как фотографии, объекты графического дизайна и литературные произведения, к которым относятся любые тексты независимо от их жанра, направленности и эстетического уровня. Забыли почему-то и про базы данных.

Закон различает собственника вебсайта, собственника вебстраницы и поставщика услуг хостинга (хост-провайдера). При отсутствии доказательств иного владельцем вебсайта считается регистрант соответствующего доменного имени, по которому осуществляется доступ к вебсайту, и (или) получатель услуг хостинга. Владелец вебсайта не является владельцем вебстраницы, если последний обладает учетной записью, что позволяет ему самостоятельно, независимо от владельца сайта, размещать информацию на вебстранице и управлять ею.

Поставщик услуг хостинга не несет ответственность за нарушение авторского права и (или) смежных прав при условии выполнения им требований ст. 52-1 закона. Теперь владельцы веб-сайтов обязаны размещать такую достоверную информацию о себе:

а) полное имя или наименование, а также полный адрес места жительства или местонахождения владельца сайта,

б) полное имя или наименование, а также полный адрес места жительства или местонахождения своего поставщика услуг хостинга;

в) контактную информацию владельца сайта и поставщика услуг хостинга, в том числе адрес электронной почты, номер телефона, по которым с ними возможно оперативно связаться.

Эта информация размещается либо на самих сайтах, либо в публичных базах данных записей о доменных именах (WHOIS).

Физические лица, не являющиеся субъектами хозяйствования, размещают в свободном доступе на сайтах, владельцами которых они являются, или в публичных базах данных записей о доменных именах (WHOIS) только контактную информацию владельца сайта. Если владелец сайта известен, то заявление о прекращении нарушения подается ему, а копия такого заявления направляется поставщику услуг хостинга. В противном случае заявление направляется только хост-провайдеру. Кроме того, непосредственно поставщику услуг хостинга подается повторное заявление, если владелец сайта проигнорировал первое заявление.

Правообладателям ничто не мешает обращаться к нарушителям и с обычной претензией либо сразу предъявлять иск в суд. Тем более, что такой вид обеспечения иска в гражданском процессе как предотвращение доступа к информации на сайтах является процедурой рассмотрения заявлений о прекращении нарушений авторского права в интернете между владельцами сайтов, страниц на сайтах и хост-провайдерами.

Выводы. Только качественная работа всех «профильных» органов государственной власти и заинтересованных организаций, совершенствование нормативно-правовой базы позволит обеспечить дальнейшее развитие института осуществления и защиты авторских прав. Однако следует заметить, что сами исследования и предложенные в них способы решения поставленной цели отстают на несколько шагов от уровня развития техники и технологий в информационной сфере. 
Это подтверждает тот факт, что современное законодательство одной страны или международного сообщества в целом полностью не могут обеспечить защиту прав интеллектуальной собственности в интернет-пространстве ни теоретически, ни практически. Возможно, исследования следовало бы обратить на пересмотр понятия «объект интеллектуальной собственности», а также на возможные пути создания специальных программных мер защиты авторских и смежных прав, для чего необходимо было бы привлечь к исследованиям и разработке таких мер защиты технических специалистов.

\section{Jumepamypa}

1. Закон Украины «Об авторском праве и смежных правах» от 23.12.93. [Электронный ресурс]: Верховная Рада Украины / Законодательство Украины. Электрон. дан. Режим доступа: https://zakon.rada.gov.ua/laws/show/3792-12.

2. Гражданский процессуальный кодекс Украины от 18.03.04. [Электронный ресурс]: Верховная Рада Украины / Законодательство Украины. Электрон. дан. Режим доступа: https://zakon.rada.gov.ua/ laws/show/1618-15.

3. Уголовный кодекс Украины от 05.04.01. [Электронный ресурс]: Верховная Рада Украины / Законодательство Украины. Электрон. дан. Режим доступа: https://zakon.rada.gov.ua/laws/ show/2341-14.

4. Alain Strowel. Peer-to-peer file Sharing and Secondary Liability in Copyright Law. UK: Edward Elgar Publishing Limited, 2009. 322 c.

\section{Аннотация}

Избаш О.О. Авторское право и интернет. - Статья.

Принимая во внимание улучшение разнообразных форм и способов нарушения авторского права в современных высокотехнологических условиях развития общества, что имеет тенденцию к глобализации, и учитывая малоэффективную систему противодействия этому негативному процессу в Украине, рассматриваемая проблема сегодня приобретает для нашего государства дополнительную актуальность.

В Украине в последние годы, к сожалению, имеет место тенденция роста количества и разнообразия нарушений авторского права, в частности пиратство и плагиат. Также не снижается уже на протяжении многих лет и остается одним из наиболее высоких в мире уровень нарушения имущественных авторских прав в сети Интернет. В соответствии с последним отчетом Международного альянса интеллектуальной собственности Украина продолжает «экспортировать пиратство, особенно цифровое, в страны ЕС, а также другие соседние страны в регионе».

Статья посвящена изучению проблем при осуществлении защиты авторских прав в сети Интернет. Автор осветил изменения в действующем законодательстве Украины по этому вопросу, а также кратко охарактеризовал недостатки в процедуре рассмотрения споров и жалоб автора, чьи права были нарушены, в системе участников предоставления интернет-ресурсов и в судебном порядке.

В соответствии с законодательством Украины за нарушение авторского права предусмотрена наряду с гражданско-правовой и административной также уголовная ответственность. Установлено, что правительством и соответствующими институтами предпринимаются определённые шаги по улучшению работы в этом направлении, которые, к сожалению, остаются малоэффективными.

Так, законодатель почему-то не воспользовался представившейся возможностью для устранения других погрешностей в формулировке ст. 176 УК, которые рассматривает А.М. Коваль в своей работе об уголовной ответственности за нарушения авторских и смежных с ним прав. Хотя при этом в статьи УК, ГПК, ХПК внесены существенные дополнения и изменения, которые позитивно влияют на защиту авторских прав. При этом следует понимать, что повышение эффективности разрешения сложной проблемы нарушений авторских прав в Украине зависит от разработки и внедрения единой государственной стратегии, в рамках которой должно произойти объединение системных и скоординированных усилий специалистов законодательной, научно-интеллектуальной, правоохранительной и государственно-управленческой сферы.

Ключевые слова: интернет, вебсайт, защита, авторское право, законодательство. 


\section{Анотація}

Ізбаш О. О. Авторське право та інтернет. - Стаття.

Беручи до уваги поліпшення різноманітних форм і способів порушення авторського права в сучасних високотехнологічних умовах розвитку суспільства, що має тенденцію до глобалізації, та враховуючи малоефективну систему протидії цьому негативному процесу в Україні, ця проблема набуває для нашої держави нині набуває додаткової актуальності.

Останніми роками в Україні, на жаль, має місце тенденція зростання кількості і різноманітності порушень авторського права, зокрема піратства та плагіату. Також не знижується і залишається одним із найбільш високих у світі рівень порушення майнових авторських прав у мережі Інтернет. Відповідно до останнього звіту Міжнародного альянсу інтелектуальної власності Україна продовжує «експортувати піратство, особливо цифрове, до країн ЄС, а також інших сусідніх країн у регіоні».

Стаття присвячена вивченню проблем при здійсненні захисту авторських прав в мережі Інтернет. Автор висвітлив зміни в чинному законодавстві України з цього питання, а також коротко охарактеризував недоліки в процедурі розгляду спорів і скарг автора, чиї права були порушені, в системі учасників надання інтернет-ресурсів і в судовому порядку.

Відповідно до законодавства України за порушення авторського права передбачена поряд із цивільно-правовою та адміністративною також кримінальна відповідальність. Встановлено, що урядом і відповідними інститутами робляться певні кроки щодо поліпшення роботи в цьому напрямі які, на жаль, залишаються малоефективними.

Так, законодавець чомусь не скористався наданою можливістю для усунення інших похибок у формулюванні ст. 176 КК, які розглядає А.М. Коваль у своїй роботі про кримінальну відповідальність за порушення авторських та суміжних з ним прав. Хоча при цьому в статті КК, ЦПК, ГПК внесені суттєві доповнення та зміни, які позитивно впливають на захист авторських прав. При цьому слід розуміти, що підвищення ефективності вирішення складної проблеми порушень авторських прав в Україні залежить від розробки та впровадження єдиної державної стратегії, в рамках якої має відбутися об'єднання системних і скоординованих зусиль фахівців законодавчої, науково-інтелектуальної, правоохоронної та державно-управлінської сфер.

Ключові слова: інтернет, вебсайт, захист, авторське право, законодавство.

\section{Summary}

Izbash O. O. Copyright law and the Internet. - Article.

Taking into account the improvement of various forms and methods of copyright infringement in modern high-tech conditions of the development of society, which tends to globalize and taking into account the ineffective system of counteracting this negative process in Ukraine, the problem under consideration today acquires additional relevance for our state.

In Ukraine, in recent years, unfortunately, there has been a tendency toward an increase in the number and variety of copyright violations, in particular piracy and plagiarism. Also, it has not been declining for many years and remains one of the highest in the world the level of copyright infringement in the Internet. In accordance with the latest report of the International Intellectual Property Alliance, Ukraine continues to "export piracy, especially digital, to EU countries, as well as other neighboring countries in the region".

The article is devoted to the study of problems in the implementation of copyright protection in the Internet. The author highlighted the changes in the current legislation of Ukraine on this issue, and also briefly described the shortcomings in the procedure for resolving disputes and complaints of the author, whose rights were violated, in the system of participants providing Internet resources and in court.

In accordance with the legislation of Ukraine, for copyright infringement, criminal liability is provided along with civil and administrative. It was established that the government and relevant institutions are taking certain steps to improve work in this direction, which, unfortunately, remain ineffective.

For example, the legislator for some reason did not seize the opportunity to eliminate other errors in the wording of Art. 176 of the Criminal Code, which Koval A.M. is considering in his work on criminal liability for violations of copyright and related rights. Although, at the same time, the articles of the Criminal Code, Code of Civil Procedure, Code of Commercial Procedure made significant amendments and additions that positively affect copyright protection. It should be understood that increasing the efficiency of resolving the complex problem of copyright infringement in Ukraine depends on the development and implementation of a unified state strategy, within the framework of which a combination of systemic and coordinated efforts of specialists in the legislative, scientific, intellectual, law enforcement and public administration spheres should occur.

Key words: internet, website, protection, copyright law, legislation. 